\title{
Current pharmacological treatments for COVID-19: A narrative review
}

\author{
Sudi Indra Jaya ${ }^{1^{*}}$, Yacobus Christian Prasetyo ${ }^{1,2}$ \\ ${ }^{1}$ Master's Programme in Biomedical Science, Faculty of Medicine, Public Health and Nursing, \\ Universitas Gadjah Mada, Yogyakarta, ${ }^{2}$ Department of Pharmacology, Faculty of Medicine, \\ Universitas Kristen Duta Wacana, Yogyakarta, Indonesia.
}

https://doi.org/10.22146/ijpther.2881

Submitted: $18 / 10 / 2021$

Accepted : 15/12/2021

Keywords:

COVID-19

SARS-CoV-2

drug treatment

RCT

clinical evidence

\section{ABSTRACT}

The coronavirus disease 2019 (COVID-19) pandemic has lasted more than one year. The number of daily cases and the number of deaths is still changing dynamically. As of this writing, specific drugs for COVID-19 are not yet available. This review aims to describe the key clinical evidence in pharmacological treatments for COVID-19. The article search process was carried out on the PubMed database with a combination of keywords ((“COVID-19") OR (“SARS-CoV-2")) AND ((“treatment”) OR (“therapy”)). In this article, there were six drugs reviewed that is corticosteroids, remdesivir, lopinavir-ritonavir, hydroxychloroquine, ivermectin, and interleukin-6 (IL-6) receptor blockers. Hydroxychloroquine, lopinavir-ritonavir, remdesivir, and ivermectin were not recommended for COVID-19 treatments regardless of disease severity and duration of symptoms. Therefore, they were excluded from the list of drugs for the treatment of COVID-19 by World Health Organization (WHO) stated strong recommendations in favor of two drugs, namely systemic corticosteroids and IL-6 receptor blockers namely tocilizumab or sarilumab. Both of them are recommended for the treatment of patients with severe and critical covid-19 so they are included in the list of COVID-19 therapeutic drugs by WHO.

\begin{abstract}
ABSTRAK
Pandemi coronavirus disease 2019 (COVID-19) telah berlangsung lebih dari setahun. Jumlah kasus harian dan jumlah kematian masih berubah secara dinamis. Sampai tulisan ini dibuat, obat spesifik untuk COVID-19 belum tersedia. Makalah ini bertujuan menunjukkan bukti klinis untuk pengobatan COVID-19. Proses penelusuran artikel dilakukan pada database PubMed dengan kombinasi kata kunci ((“COVID-19”) OR (“SARS-CoV-2”)) AND ((“treatment”) OR (“therapy”)). Dalam artikel ini, ada enam obat yang ditelaah yaitu kortikosteroid, remdesivir, lopinavir-ritonavir, hydroxychloroquine, ivermectin, dan penghambat reseptor IL-6. Hidroksiklorokuin, lopinavir-ritonavir, remdesivir, dan ivermectin tidak direkomendasikan untuk terapi pasien COVID-19 pada semua tingkat keparahan penyakit dan durasi munculnya gejala sehingga dikeluarkan dari daftar obat untuk pengobatan COVID-19 oleh World Health Organization (WHO). Selanjutnya, WHO menyatakan rekomendasi kuat yang mendukung dua obat, yaitu kortikosteroid sistemik dan penghambat reseptor IL-6 yaitu tocilizumab atau sarilumab. Kedua obat ini direkomendasikan untuk pengobatan pasien COVID-19 derajat berat dan kritis sehingga masuk dalam daftar obat untuk pengobatan COVID-19 oleh WHO.
\end{abstract}




\section{INTRODUCTION}

The World Health Organization (WHO) on March 11, 2020, has declared the novel coronavirus disease 2019 (COVID-19) outbreak a global pandemic. ${ }^{1}$ COVID-19 is caused by the severe acute respiratory syndrome coronavirus-2 (SARS-CoV-2) that was first identified in Wuhan, Hubei province, China, in December 2019. ${ }^{2}$

As of $17^{\text {th }}$ September 2021, WHO reported 4.6 million deaths worldwide. ${ }^{3}$ The number of confirmed cases varies widely between countries. Although some areas in the world are seeing a drop in cases, some countries are experiencing a significant surge in COVID-19 cases. Indonesia reported a total of 4,185,144 cumulative confirmed case on September $17^{\text {th }}, 2021$ with 140,138 cumulative death (case fatality rate/CFR $=3.3 \%$ ). ${ }^{4}$

The transmission of SARS-CoV-2 is believed to be through aerosols and respiratory droplets. When an infected person coughs, sneezes, or talks, aerosols, and droplets containing the virus particles are generated. Besides the infected person, there are other sources of aerosol and droplets such as some medical and surgical procedures, toilet flushes, and running tap water. ${ }^{5}$ It has been speculated that environmental factors such as crowding, adequacy of ventilation, indoor or outdoor setting, and size of the indoor space may be related to the virus spread. ${ }^{6,7}$

The common symptoms of SARSCoV-2 infection are fever (83\%-98\%), cough (50\%-82\%), fatigue (25\%-44\%), shortness of breath (19\%-55\%), and myalgia (11\%-44\%). ${ }^{8}$ Loss of the sense of smell (anosmia) or loss of taste sensation (ageusia) in conjunction with respiratory symptoms has also been reported. . $^{90}$ Study from Alene et al. ${ }^{11}$ reported that one-fourth of SARS-CoV-2 infections remained asymptomatic throughout the course of infection.

Effective treatments for COVID-19 patients are urgently needed. The rising number of research and clinical trials for COVID-19 has burdened healthcare providers and policymakers to stay up to date.

\section{MATERIALS AND METHODS}

This review aims to describe the key clinical evidence in pharmacological therapies for COVID-19. The article search process was carried out on the PubMed database with a combination of keywords ((“COVID-19”) OR (“SARS-CoV-2”)) AND ((“treatment”) OR (“therapy”)). We strived to obtain high quality evidence in the form of randomize control trials (RCT). However, non-clinical studies (both in experimental animals and in vitro) are also used as a reference to enrich the discussion of this narrative review. The writing of this review only includes articles that are available in English.

\section{DISCUSSION}

\section{Corticosteroids}

Corticosteroids are a class of steroid hormones released by the adrenal cortex, which includes glucocorticoids and mineralocorticoids. The term "corticosteroids" is generally used to refer to glucocorticoids. It is one of the most widely prescribed drugs in the world due to its prominent immunemodulatory actions. ${ }^{12}$ Glucocorticoids have been widely used in syndromes closely related to COVID-19, including severe acute respiratory syndrome (SARS), Middle East respiratory syndrome (MERS), severe influenza, and community-acquired pneumonia. The RECOVERY trial provides evidence that treatment with dexamethasone at a dose of $6 \mathrm{mg}$ once daily for up to 10 days reduces 28-day mortality in patients with COVID-19 who are receiving respiratory support in the form of non-invasive oxygenation and invasive mechanical ventilation. The incidence of death in the dexamethasone group was lower compared to the usual care group on subject who receive invasive mechanical 
ventilation $(29.3 \%$ vs $41.4 \%$; $\mathrm{RR}=0.64$; 95\% confidence interval [CI] 0.510.81 ) and on subject with non-invasive oxygenation $(23.3 \%$ vs $26.2 \%$; $R R=0.82$; $95 \%$ CI $0.72-0.94)$. On the other hand, the incidence of death is higher in the dexamethasone group compared to the usual group among patients who were not receiving any respiratory support (17.8\% vs $14.0 \%$; RR $=1.19$; 95\%CI 0.91 1.55). ${ }^{13}$ Another clinical trial in Brazil, the COVID-19 Dexamethasone (CoDEX) Trial found that intravenous dexamethasone plus standard care, compared with standard of care alone, resulted in a statistically significant increase in the number of days alive and free of mechanical ventilation over 28 days. Patients in the dexamethasone group had a mean 6.6 ventilator-free days (95\% CI 5.0-8.2) during the first 28 days vs 4.0 ventilator-free days $(95 \%$ CI $2.9-5.4)$ in the standard care group (difference, 2.26; 95\% CI 0.2-4.38; $\mathrm{p}=0.04) .{ }^{14}$

Another prematurely closed trial found that the short-term early use of corticosteroids could suppress the immune cells, which may prolong SARSCoV-2 shedding in patients with COVID-19 pneumonia. ${ }^{15}$ This study highlights the concerns of balancing benefit and harm on treating patients with systemic corticosteroids. Another important point is that this trial used methylprednisolone, while the RECOVERY Trial and CoDEX Trial in Brazil utilizes dexamethasone. Another study in Iran compares methylprednisolone and dexamethasone in patients hospitalized with COVID-19 who receive supplemental oxygen, they found that methylprednisolone demonstrated better results compared to dexamethasone. Those who received methylprednisolone ended up with significantly better clinical status compared to the dexamethasone group at day 5 (4.02 vs. $5.21, \mathrm{p}=0.002)$ and day 10 (2.90 vs. $4.71, \mathrm{p}=0.001$ ) of admission. The mean length of hospital stay was $7.43 \pm 3.64$ and $10.52 \pm 5.47$ days in the methylprednisolone and dexamethasone groups, respectively $(p=0.015)$.
Another corticosteroid drug used in the pharmacological treatment for COVID-19 was hydrocortisone. The REMAP CAP trial which involves eight countries found that among patients with severe COVID-19, treatment with a 7-day fixed-dose course of hydrocortisone or shock-dependent dosing of hydrocortisone, compared with no hydrocortisone, resulted in 93\% and $80 \%$ probabilities of superiority concerning the odds of improvement in organ support-free days within 21 days. Organ support-free days defined as days alive and free of ICU-based respiratory or cardiovascular support within 21 days. However, the trial was stopped early and no treatment strategy met prespecified criteria for statistical superiority. ${ }^{16}$

The rationale behind systemic corticosteroid use is to mitigate inflammatory organ injury in viral pneumonia caused by SARS-CoV-2. However, the benefit of corticosteroid use is only found in patients with COVID-19 on oxygen supplementation or respiratory support. ${ }^{13}$ WHO recommend systemic corticosteroid for the treatment of patients with severe and critical COVID-19. On the other hand, WHO suggests not to use corticosteroids in the treatment of patients with non-severe COVID-19. ${ }^{17,18}$

\section{Remdesivir}

Remdesivir is a novel monophosphoramidate nucleoside prodrug, which is when metabolized to its active compound, inhibits viral RNA synthesis. ${ }^{19}$ Remdesivir has been observed to have an in vitro and in vivo antiviral activity against SARS-CoV-2. ${ }^{20}$

Remdesivir showed some beneficial effects toward ameliorating the conditions in patients with COVID-19, such as shortening of time to recovery ${ }^{21,22}$ or clinical status. ${ }^{23}$ A scoping review of 17 empirical studies and 23 clinical trial registrations concluded that remdesivir might shorten time to clinical improvement in adults with severe COVID-19, with a similar proportion 
of adverse events in both therapy and control groups. ${ }^{24} \mathrm{~A}$ systematic review with network meta-analysis of five RCTs concluded that remdesivir could help improving the clinical outcome of hospitalized patients with COVID-19, with a 5-day regimen might be sufficient compared to a 10-day regimen..$^{25}$ As a combination, baricitinib and remdesivir for COVID-19 patients were superior to remdesivir alone in reducing recovery time and accelerating clinical status. ${ }^{26}$ Remdesivir appeared to be as tolerable as other comparators or placebo, ${ }^{25}$ such as in COVID-19 patients on hemodialysis. ${ }^{22}$

Some studies reported no significant effect observed with remdesivir usage. NOR-Solidarity trial reported that remdesivir did not affect viral clearance in hospitalized COVID-19 patients. $^{27}$ In a combination, one study found no difference in mortality outcome between remdesivir-tocilizumab therapy compared to tocilizumab alone. Some minimal/non-use of ventilation benefit was even observed in the tocilizumab alone group, compared to the combination. ${ }^{28}$. One systematic review with meta-analysis and trial sequential analysis of five RCTs with 7540 participants reported an unclear to high-risk bias with most studies. It was then concluded that there was insufficient evidence to support the use of remdesivir for COVID-19 treatment, as more high-quality RCTs are needed for stronger evidence. ${ }^{29}$

WHO recommends against administering remdesivir in addition to usual care. The recommendation is conditional, that is if remdesivir is considered, it is contraindicated in those with liver (ALT $>5$ times normal baseline) or renal (eGFR $<30 \mathrm{~mL} / \mathrm{min}$ ) dysfunction. The recommendation for remdesivir was published as early as 20 November 2020, on its second living guideline, following the WHO SOLIDARITY trial, in which the treatment with remdesivir, hydroxychloroquine, and lopinavir-ritonavir for patients with COVID-19 was reported. Since then, the recommendation remained unchanged until the 6th version of the living guideline. The recommendation was based on the lack of evidence found by the WHO Guideline Development Group (GDG). The low certainty evidence that remdesivir improved the outcomes of COVID-19 patients included, but was not limited to, reduced mortality, the need for mechanical ventilation, and time to clinical improvement. There was, however, no evidence of increased severe adverse events found from the trials. The overall credibility of the subgroup effect was also judged to be insufficient to make subgroup recommendations. Considering the overall low certainty evidence of remdesivir benefit and harm, driven by the risk of bias and imprecision limitations of the included studies, it was interpreted that remdesivir possibly had little to no benefit compared with usual care and further pharmacovigilance was needed, even though this did not prove that remdesivir is ineffective. ${ }^{17,18}$

\section{Lopinavir-ritonavir}

Lopinavir and ritonavir are antiviral drugs with protease inhibitor activity that have been established as antivirals for HIV-1 and 2.30 The combination of both drugs increases their plasma halflife. Interests in lopinavir for COVID-19 therapy were based on its antiprotease activity for SARS coronavirus (SARS CoV), which is proved in vitro against SARSCoV, SARS-CoV-2, and MERS-CoV. ${ }^{31-33}$

In one trial, the lopinavir-ritonavir treatment showed no benefit beyond standard care, though the standard care group experienced a more serious adverse event, while gastrointestinal adverse events were observed in the lopinavir-ritonavir group. Due to the adverse events, however, lopinavirritonavir treatment had to be stopped early for 13 patients. ${ }^{34}$ Another trial randomized 694 COVID-19 patients into receiving lopinavir-ritonavir, hydroxychloroquine, a combination of both,ornoantiviraltherapyascontrol. The trial concluded that lopinavir-ritonavir 
alone, hydroxychloroquine alone, or in combination worsened the outcomes compared to control. ${ }^{35}$ DisCoVeRy trial, conducted as an add-on to the Solidarity Trial, reported no improvement of clinical status nor SARS-CoV-2 clearance for patients with lopinavir-ritonavir therapy, or in its combination with IFN$\beta-1 \mathrm{a}$ and hydroxychloroquine. ${ }^{3}$ For early treatment of COVID-19, a trial of 685 patients, found no significant benefit for decreasing COVID-19 associated hospitalization or any secondary outcomes. ${ }^{37}$ A multicentre, prospective, open-label phase 2 study enrolling 127 patients with positive nasopharyngeal swabs, assessed a triple combination of IFN- $\beta-1 b$, lopinavir-ritonavir, and ribavirin, compared to lopinavirritonavir alone. The study yielded a superior result from the combination group compared to the monotherapycontrol group. However, as the paper authors stated, the study had several limitations such as no placebo group, and confounding factor of a subgroup omitting IFN- $\beta-1 \mathrm{~b}$, which the author suggested appear to be a key component of the combination. ${ }^{38} \mathrm{~A}$ rather large RCT, the RECOVERY trial, randomized 1616 patients for the lopinavir-ritonavir group and 3424 patients to receive usual care. Yet it was concluded that lopinavirritonavir was not associated with a reduction in 28-day mortality, duration of hospital stay, or risk of progressing to invasive mechanical ventilation or death, and therefore the findings did not support the use of lopinavir-ritonavir for COVID-19 patients. ${ }^{39}$

The use of lopinavir-ritonavir was addressed since the $3^{\text {rd }}$ WHO living guideline, and no change was made until the $6^{\text {th }}$ version, that is, WHO recommended against the administration of lopinavir-ritonavir for treatment of COVID-19 of any severity. Within the evidence of a linked systematic review and NMA of 7 RCTs, with 7429 COVID-19 patients, the WHO GDG panel found a lack of evidence for some key outcomes was found. The evidence for mortality and need for mechanical ventilation was moderate certainty, whereas the evidence for other outcomes such as time for clinical improvement and others. Lopinavir-ritonavir might increase the risk of diarrhea and nausea-vomiting, even though the evidence was of low certainty. The effects of viral clearance and acute kidney injury were uncertain. No effect modification of illness severity was found in subgroup analysis. Even though Lopinavir-ritonavir is not very costly compared to other drugs and is generally available in health care settings, WHO reminds the importance of not drawing attention and resources away from the best supportive care of the use of corticosteroid in severe COVID-19. ${ }^{17,18}$

\section{Hydroxychloroquine}

Hydroxychloroquine is an antimalarial medication that is commonly used for the treatment and prophylaxis of malaria. This drug receives attention in the pharmacological treatment of COVID-19 because of the anti-inflammatory effect on the immune systems. Several of the anti-inflammatory mechanisms include interference with lysosomal acidification and antigen presentation, inhibition of toll-like receptor signals, inhibition of $\mathrm{T}$ and $\mathrm{B}$ cell receptors, and especially, decreasing cytokine production by macrophages such as IL-1 and IL-6. ${ }^{40,41}$

WHO Solidarity trial results show that hydroxychloroquine had little or no effect on hospitalized patients with COVID-19. Death occurred in 104 of 947 patients receiving hydroxychloroquine and in 84 of 906 receiving its control (RR $1.19 ; 95 \%$ CI 0.89 to $1.59 ; \mathrm{p}=0.23$ ). The main outcomes of mortality were not reduced by this medication. A systematic review and network meta-analysis found that hydroxychloroquine do not appear to have any important impact on patient-important outcomes such as mortality, the chance of mechanical ventilation, viral clearance in seven days, admission to hospital, duration of 
hospital stay, ventilator-free days, time to symptom resolution, and time to viral clearance. ${ }^{42}$

The third version of the WHO living guideline addressed the use of hydroxychloroquine in patients with COVID-19. WHO made a strong recommendation against using hydroxychloroquine or chloroquine for the treatment of COVID-19. This recommendation applies to patients with any disease severity and any duration of symptoms.

\section{Ivermectin}

Ivermectin is an anti-parasitic drug mainly used in onchocerciasis and strongyloidiasis. ${ }^{43}$ Interest in Ivermectin as a possible COVID-19 therapy first arose in early 2020 when a study reported that the drug showed an inhibitory effect of SARS-CoV-2 in vitro. The authors claimed a 5000-fold reduction in the viral RNA at 48 hours in the cell culture model. ${ }^{44}$ Since then, many studies have aimed to prove the effectiveness of Ivermectin for COVID-19 therapy.

Some studies observed promising beneficial effects of Ivermectin use for COVID-19 patients. In one study, a doubleblind RCT reported an improvement of clinical features of COVID-19, including dyspnoea, cough, and lymphopenia. The study also claimed that a single weightbased dose of ivermectin $(0.2 \mathrm{mg} / \mathrm{kg})$ was well-tolerated among the patients. ${ }^{45}$ Another trial combined ivermectin with doxycycline and reported an earlier recovery compared to control, and less likely to progress to a more serious phase, and more likely to be tested negative by RT-PCR on day $14 .{ }^{46} \mathrm{~A}$ meta-analysis assessed the association between the use of ivermectin and mortality in COVID-19 patients. The study included six RCTs with a total of 658 patients with COVID-19, in which a preliminary mortality beneficial effect with ivermectin use was observed..$^{47}$ Local use of Ivermectin was a subject of research as well. A prospective clinical trial with 114 mild COVID-19 patients assessed the therapeutic efficacy of Ivermectin nanosuspension intranasal spray. The trial concluded that local use of the spray was safe and effective, proven by rapid viral clearance and shortening of anosmia duration in the group treated with the Ivermectin spray. ${ }^{48}$ A prophylaxis RCT, conducted in Argentina, aimed to evaluate the protective effect of intensive short-term treatment with Ivermectin and IotaCarrageenan combination, given as oral and nasal spray for health workers. The result was that the treatment reduced the number of health workers infected with COVID-19. 49

However, not all studies yield the beneficiary result of ivermectin used in COVID-19. A double-blind RCT aimed to determine whether Ivermectin prove to be efficacious for mild COVID-19, concluded that a 5-day course of ivermectin did not significantly improve the symptom resolution time, compared to placebo. ${ }^{50}$ An almost similar result was observed in a double-blind RCT with single-dose ivermectin in mild and moderate COVID-19. In this study, single oral administration of Ivermectin did not significantly increase the negativity of RT-PCR or decline in day 5 viral load. ${ }^{51}$ Another double-blind RCT reported that ivermectin had no significant effect on hospitalization prevention, and the ivermectin group even required invasive mechanical ventilatory support earlier than the placebo group. ${ }^{52}$

Until its latest living guideline $\left(^{\text {th }}\right.$ version, dated 24 September 2021), WHO recommended not to use Ivermectin in patients with COVID-19, outside of clinical trial settings. This recommendation is based on the very low certainty of the evidence of most key outcomes such as mortality, mechanical ventilation, hospital admission, duration of hospitalization, and viral clearance in many studies, and therefore, the effect of Ivermectin on these outcomes remains uncertain. The very low certainty of the evidence consists of serious imprecision for most outcomes and wide confidence intervals of the aggregate data. Risk of 
bias for some outcomes also noted, such as lack of blinding or lack of trial preregistrationinsometrials, and publication bias in one trial. Some low certainty evidence showed that ivermectin also might have little to no effect on clinical improvement, and even might increase the risk of adverse events. The fact that Ivermectin is widely available and at a relatively low cost does not mandate its use because any benefit remains very uncertain with ongoing concerns regarding the harms. Continuous use of Ivermectin potentially contributes to drug shortages for helminth control and elimination programs. Ivermectin, however, may still be used anyway in areas with strongyloidiasis endemic, at the discretion of the clinicians overseeing the treatment, but not for treatment of COVID-19 itself. $^{18,42}$

\section{Interleukin-6 receptor blockers}

COVID-19 is associated with maladaptive immune response leading to excessive inflammation and organ injury. ${ }^{53}$ clinical criteria specifically to define COVID-19-associated hyperinflammatory syndrome (cHIS One of the prominent inflammatory mediators is IL-6, a cytokine produced by macrophages that induces a proinflammatory response..$^{54}$ Elevated level of blood IL-6 were commonly seen in patients with severe COVID-19. ${ }^{55}$

Clinical trials of two IL-6 receptor blockers found promising results. Tocilizumab and sarilumab improve organ support-free days in patients with COVID-19 who were admitted to the intensive care unit and receive respiratory or cardiovascular organ support. The median number of organ support-free days was 10 (interquartile range [IQR] -1 to 16) in the tocilizumab group, 11 (IQR, 0 to 16) in the sarilumab group, and 0 (IQR -1 to 15 ) in the control group. ${ }^{56}$ The RECOVERY Trial found that treatment with tocilizumab reduces mortality. The primary outcomes of all-cause mortality were assessed at 28 days after randomization to tocilizumab versus usual care. Mortality occurred in 621 (31\%) of the 2022 patients allocated with tocilizumab and 729 (35\%) of the 2094 allocated to usual care (RR 0.85; 95\% CI $0.76-0.94 ; \mathrm{p}=0.0028$ ). Treatment with tocilizumab also increases the chances of hospital discharge within 28 days (RR 1.2; 95\% CI 1.12-1.33; $\mathrm{p}=<0.0001$ ), and reduces the chances of requiring invasive mechanical ventilation (RR 0.84; 95\% CI 0.77-0.92; $\mathrm{p}=<0.0001) .{ }^{57}$ Report from EMPACTA trial informs us about the safety and efficacy of tocilizumab in hospitalized patients with COVID-19 pneumonia who were not receiving mechanical ventilation. The cumulative percentage of patients who had received mechanical ventilation or who had died by day 28 was $12.0 \%$ (95\% CI $8.5-16.9$ ) in the tocilizumab group and $19.3 \%$ (95\% CI 13.3- 27.4) in the placebo group (hazard ratio for mechanical ventilation or death, 0.56 ; $95 \%$ CI 0.33 to $0.97 ; \mathrm{p}=$ 0.04 by the log-rank test). Tocilizumab reduced the likelihood of progression to the composite outcome of mechanical ventilation or death. ${ }^{58}$

Another multinational trial with sarilumab reaches a different conclusion. The trial did not show the efficacy of sarilumab in patients admitted to the hospital with COVID-19 and receiving supplemental oxygen. The primary endpoint is time to improvement of two or more points on a seven-point clinical assessment scale. No significant difference was observed between sarilumab doses and placebo up to day 29. A potential reason as to why sarilumab was not effective in this trial might be because targeting IL-6 alone is inadequate to suppress the hyperinflammation phase of COVID-19. IL-6 antagonists and cytokine inhibition, in general, have not been effective in other forms of sepsis where levels of IL-6 are comparable with COVID-19.59 A retrospective study from New York City Hospital found similar results with tocilizumab. There was no evidence to support an improvement in hypoxemia or ventilator-free survival with the use 
of tocilizumab $400 \mathrm{mg}$ in the absence of corticosteroids. ${ }^{60}$ COVACTA, a phase 3 , international, randomized, doubleblind, placebo-controlled trial, to assess the efficacy and safety of tocilizumab in hospitalized patients with severe COVID-19 also found no significant difference in clinical status between the tocilizumab group and the placebo group at day $28 .{ }^{61}$

The WHO living guideline recommends treatment with IL-6 receptor blockers (tocilizumab or sarilumab) for patients with severe or critical COVID-19. Compared with other treatment recomendations for COVID-19, IL-6 receptor blockers are expensive. WHO recommendation does not take into account cost-effectiveness. The trials of IL-6 receptor blockers were mostly performed in high-income countries. Lower-middle countries might be facing challenges to access this medication. However, this strong recommendation should provide a stimulus to improve equity and global access to these treatments. ${ }^{17,18}$

TABLE 1. Summary of WHO recommendations

\begin{tabular}{|c|c|c|}
\hline \multirow{2}{*}{$\begin{array}{l}\text { Pharmacological } \\
\text { Treatments (Drug } \\
\text { Classes/Name) }\end{array}$} & \multicolumn{2}{|c|}{ COVID-19 disease severity } \\
\hline & Non-Severe & Critical \\
\hline Systemic corticosteroids & $\begin{array}{l}\text { Weak recommendation } \\
\text { against }\end{array}$ & $\begin{array}{l}\text { Strong recommendation in } \\
\text { favor }\end{array}$ \\
\hline Remdesivir & \multicolumn{2}{|c|}{ Weak recommendation against } \\
\hline Lopinavir-ritonavir & \multicolumn{2}{|c|}{ Strong recommendation against } \\
\hline Hydroxychloroquine & \multicolumn{2}{|c|}{ Strong recommendation against } \\
\hline Ivermectin & \multicolumn{2}{|c|}{ Recommendation against except in clinical trials } \\
\hline $\begin{array}{l}\text { Interleukin-6 receptor } \\
\text { Blockers }\end{array}$ & \multicolumn{2}{|c|}{$\begin{array}{c}\text { Strong recommendation in } \\
\text { favor }\end{array}$} \\
\hline
\end{tabular}

\section{CONCLUSION}

Specific pharmacological treatment for COVID-19 is not yet available. Several recommendations have been made by WHO for some particular drugs to be used as the pharmacological treatment of COVID-19. Hydroxychloroquine, lopinavir-ritonavir, remdesivir, and ivermectin were not recommended for COVID-19 treatments regardless of disease severity and duration of symptoms. Therefore, theywere excluded from the list of drugs for the treatment of COVID-19 by WHO. WHO stated strong recommendations in favor of two drugs, namely systemic corticosteroids and tocilizumab or sarilumab. Both of them are recommended for the treatment of patients with severe and critical covid-19 so they are included in the list of COVID-19 therapeutic drugs by WHO.

\section{ACKNOWLEDGEMENT}

The authors would like to thank Professor Erna Kristin for providing a critical review of the manuscript.

\section{REFERENCES}

1. WHO Director-General's opening remarks at the media briefing on COVID-19 - 11 March 2020 [Internet]. Geneva: World Health Organization. 2020. Available from: https:// www.who.int/director-general/ speeches/detail/who-directorgeneral-s-opening-remarks-at-themedia-briefing-on-covid-19---11march-2020

2. Wei M, Yang N, Wang F, Zhao G, Gao 
H, Li Y. Epidemiology of coronavirus disease 2019 (COVID-19) caused by severe acute respiratory syndrome coronavirus 2 (SARS-CoV-2). Disaster Med Public Health Prep 2020; 14(6):796-804.

https://doi.org/10.1017/dmp.2020.155

3. World Health Organization. WHO COVID-19 dashboard. Geneva: World Health Organization. 2020. Available from: https://covid19.who.int

4. Indonesian Ministry of Health. COVID-19 Situation update $18^{\text {th }}$ September 2021. Jakarta: Indonesia Ministry of Health, 2021. Available from: https:// infeksiemerging.kemkes.go.id/ situasi-infeksi-emerging/situasiterkini-perkembangan-coronavirusdisease-covid-19-18-september-2021

5. Rabaan AA, Al-Ahmed SH, AlMalkey MK, Alsubki RA, Ezzikouri $\mathrm{S}$, Al-Hababi $\mathrm{FH}$, et al. Airborne transmission of SARS-CoV-2 is the dominant route of transmission: droplets and aerosols. Infez Med 2021; 29(1):10-9.

6. Jung J, Lee J, Kim E, Namgung S, Kim Y, Yun M, et al. Frequent occurrence of SARS-CoV-2 transmission among non-close contacts exposed to COVID-19 patients. J Korean Med Sci 2021; 36(33):1-6. https://doi.org/10.3346/jkms.2021.36.e233

7. Morawska L, Milton DK. It is time to address airborne transmission of coronavirus disease 2019 (COVID-19). Clin Infect Dis 2020; 71(9):2311-3. https://doi.org/10.1093/cid/ciaa939

8. TsaiPH,LaiWY, Lin YY,Luo YH,Lin YT, Chen HK, et al. Clinical manifestation and disease progression in COVID-19 infection. J Chinese Med Assoc 2021; 84(1):3-8.

h t t p s://d o i.org/10.1097/ JCMA.0000000000000463

9. Tong JY, Wong A, Zhu D, Fastenberg $\mathrm{JH}$, Tham T. The prevalence of olfactory and gustatory dysfunction in COVID-19 patients: a systematic review and meta-analysis. Otolaryngol - Head Neck Surg (United
States) 2020; 163(1):3-11.

$\mathrm{h}$ t $\mathrm{t}$ p $\mathrm{s}$ : $/$ / $/ \mathrm{d}$ o $\mathrm{i}$. org $/ 10.1177 / 0194599820926473$

10. Spinato G, Fabbris C, Polesel J, Cazzador D, Borsetto D, Hopkins C, et al. Alterations in smell or taste in mildly symptomatic outpatients with SARS-CoV-2 infection. JAMA 2020; 323(20):2089-90.

https://doi.org/10.1001/jama.2020.6771

11. Alene M, Yismaw L, Assemie MA, Ketema DB, Mengist B, Kassie B, et al. Magnitude of asymptomatic COVID-19 cases throughout the course of infection: A systematic review and meta-analysis. PLoS One 2021; 16(3):1-11.

http://dx.doi.org/10.1371/journal. pone.0249090

12. Ramamoorthy S, Cidlowski JA. Corticosteroids: mechanisms of action in health and disease. Rheum Dis Clin North Am 2016; 42(1):15-31. https://doi.org/10.1016/j.rdc.2015.08.002

13. The RECOVERY Collaborative Group. Dexamethasone in hospitalized patients with COVID-19. N Engl J Med 2021; 384(8):693-704.

https://doi.org/10.1056/NEJMoa2021436

14. Tomazini BM, Maia IS, Cavalcanti $\mathrm{AB}$, Berwanger $\mathrm{O}$, Rosa RG, Veiga $\mathrm{VC}$, et al. Effect of dexamethasone on days alive and ventilatorfree in patients with moderate or severe acute respiratory distress syndrome and COVID-19: The CoDEX Randomized Clinical Trial. JAMA 2020; 324(13):1307-16.

https://doi.org/10.1001/jama.2020.17021

15. Tang X, Feng Y-M, Ni J-X, Zhang J-Y, Liu L-M, Hu K, et al. Early use of corticosteroid may prolong SARSCoV-2 shedding in non-intensive care unit patients with COVID-19 pneumonia: a multicenter, singleblind, randomized control trial. Respiration 2021; 100(2):116-26. https://doi.org/10.1159/000512063

16. Angus DC, Derde L, Al-Beidh F, Annane D, Arabi Y, Beane A, et al. Effect of hydrocortisone on mortality and organ support in patients with 
severe COVID-19: The REMAP-CAP COVID-19 Corticosteroid Domain Randomized Clinical Trial. JAMA 2020; 324(13):1317-29.

https://doi.org/10.1001/jama.2020.17022

17. Lamontagne F, Agoritsas T, MacDonald H, Leo YS, DIaz J, Agarwal $\mathrm{A}$, et al. A living WHO guideline on drugs for COVID-19. BMJ 2020; 370:m33379.

18. World Health Organization. Therapeutics and COVID-19: living guideline. Geneva: World Health Organization 2021.

19. Malin JJ, Suárez I, Priesner V, Fätkenheuer G. Remdesivir against COVID-19 and other viral diseases. Clin Microbiol Rev 2021; 34(1):1-21. https://doi.org/10.1128/CMR.00162-20

20. Wang $M$, Cao R, Zhang L, Yang $X$, Liu J, Xu M, et al. Remdesivir and chloroquine effectively inhibit the recently emerged novel coronavirus (2019-nCoV) in vitro. Cell Res 2020; 30(3):269-71. https://doi.org/10.1038/s41422-020-0282-0

21. Beigel JH, Tomashek KM, Dodd LE, Mehta AK, Zingman BS, Kalil AC, et al. Remdesivir for the treatment of COVID-19: Final report. N Engl J Med 2020; 383(19):1813-26.

https://doi.org/10.1056/NEJMoa2007764

22. Aiswarya D, Arumugam V, Dineshkumar T, Gopalakrishnan $\mathrm{N}$, Lamech TM, Nithya $\mathrm{G}$, et al. Use of remdesivir in patients with COVID-19 on hemodialysis: a study of safety and tolerance. Kidney Int Reports 2021; 6(3):586-93.

https://doi.org/10.1016/j.ekir.2020.12.003

23. Spinner CD, Gottlieb RL, Criner GJ, Arribas Lopez JR, Cattelan AM, Soriano Viladomiu A, et al. Effect of remdesivir vs standard care on clinical atatus at 11 days in patients with moderate COVID-19: A randomized clinical trial. JAMA 2020; 24(11):1048-57.

https://doi.org/10.1001/jama.2020.16349

24. Pimentel J, Laurie C, Cockcroft A, Andersson N. Clinical studies assessing the efficacy, effectiveness and safety of remdesivir in management of COVID-19: A scoping review. Br J Clin Pharmacol 2021; 87(7):2663-84. https://doi.org/10.1111/bcp.14677

25. Lai $\mathrm{C}-\mathrm{C}$, Chen $\mathrm{C}-\mathrm{H}$, Wang $\mathrm{C}-\mathrm{Y}$, Chen K-H, Wang Y-H, Hsueh P-R. Clinical efficacy and safety of remdesivir in patients with COVID-19: a systematic review and network meta-analysis of randomized controlled trials. J Antimicrob Chemother 2021; 76(8):1962-8.

https://doi.org/10.1093/jac/dkab093

26. Kalil AC, Patterson TF, Mehta AK, Tomashek KM, Wolfe CR, Ghazaryan $\mathrm{V}$, et al. Baricitinib plus remdesivir for hospitalized adults with COVID-19. N Engl J Med 2021; 384(9):795-807.

https://doi.org/10.1056/NEJMoa2031994

27. Barratt-Due A, Olsen IC, NezvalovaHenriksen K, Kåsine T, LundJohansen F, Hoel H, et al. Evaluation of the Effects of Remdesivir and Hydroxychloroquine on Viral Clearance in COVID-19. Ann Intern Med 2021; 174(9):1261-9.

https://doi.org/10.7326/M21-0653

28. Almaghlouth NK, Anyiam FE, Shah S, Haq S, Attia MJ, Guevara R, et al. The use of single therapy with tocilizumab versus combination therapy with remdesivir and tocilizumab in SARSCoV-2 Patients in El Paso, Texas. Cureus 2021; 13(7):e16351 https://doi.org/10.7759/cureus.16351

29. Okoli GN, Rabbani R, Copstein L, AlJuboori A, Askin N, Abou-Setta AM. Remdesivir for coronavirus disease 2019 (COVID-19): a systematic review with meta-analysis and trial sequential analysis of randomized controlled trials. Infect Dis 2021; 53(9):691-9.

https://doi.org/10.1080/14787210.202 1.1961579

30. Setiabudy R, Louisa M. Antivirus. In: Gunawan SG, Setiabudy R, Nafrialdi, Instiaty, editors. Farmakologi dan Terapi $6^{\text {th }}$ ed. Jakarta: Fakultas Kedokteran Universitas Indonesia 2016. p.660-1. 
31. Choy KT, Wong AYL, Kaewpreedee P, Sia SF, Chen D, Hui KPY, et al. Remdesivir, lopinavir, emetine, and homoharringtonine inhibit SARSCoV-2 replication in vitro. Antiviral Res 2020; 178:104786.

h t tp s://doi.org/10.1016/j . antiviral.2020.104786

32. De Wilde AH, Jochmans D, Posthuma CC, Zevenhoven-Dobbe JC, Van Nieuwkoop S, Bestebroer $\mathrm{TM}$, et al. Screening of an FDAapproved compound library identifies four small-molecule inhibitors of Middle East respiratory syndrome coronavirus replication in cell culture. Antimicrob Agents Chemother 2014; 58(8):4875-84. https://doi.org/10.1128/AAC.03011-14

33. Liu X, Wang X-J. Potential inhibitors against 2019-nCoV coronavirus M protease from clinically approved medicines. J Genet Genomics 2020; 47(2): 119-21.

https://doi.org/10.1101/2020.01.29.924100

34. Cao B, Wang Y, Wen D, Liu W, Wang J, Fan G, et al. A Trial of lopinavirritonavir in adults hospitalized with severe COVID-19. N Engl J Med 2020; 382(19):1787-99.

https://doi.org/10.1056/NEJMoa2001282

35. Arabi YM, Gordon AC, Derde LPG, Nichol AD, Murthy S, Beidh F Al, et al. Lopinavir-ritonavir and hydroxychloroquine for critically ill patients with COVID-19: REMAPCAP randomized controlled trial. Intensive Care Med 2021; 47(8):867-86.

36. Ader F, Peiffer-Smadja N, Poissy J, Bouscambert-Duchamp M, Belhadi $\mathrm{D}$, Diallo A, et al. An open-label randomized controlled trial of the effect of lopinavir/ritonavir, lopinavir/ritonavir plus IFN- $\beta-1 \mathrm{a}$ and hydroxychloroquine in hospitalized patients with COVID-19. Clin Microbiol Infect 2021; 27(12):1826-37. https://doi.org/10.1016/j.cmi.2021.05.020

37. Reis G, Moreira Silva EADS, Medeiros Silva DC, Thabane L, Singh G, Park JJH, et al. Effect of early treatment with hydroxychloroquine or lopinavir and ritonavir on risk of hospitalization among patients with COVID-19: The TOGETHER Randomized Clinical Trial. JAMA 2021; 4(4):e216468.

h t t p s://d o i.org / $10.1001 /$ jamanetworkopen.2021.6468

38. Hung IFN, Lung KC, Tso EYK, Liu R, Chung TWH, Chu MY, et al. Triple combination of interferon beta-1b, lopinavir-ritonavir, and ribavirin in the treatment of patients admitted to hospital with COVID-19: an openlabel, randomised, phase 2 trial. Lancet 2020; 395(10238):1695-704.

http://dx.doi.org/10.1016/S01406736(20)31042-4

39. RECOVERY Collaborative Group. Lopinavir-ritonavir in patients admitted to hospital with COVID-19 (RECOVERY): a randomised, controlled, open-label, platform trial. Lancet 2020; 396(10259):1345-52.

40. Ben-Zvi I, Kivity S, Langevitz P, Shoenfeld Y. Hydroxychloroquine: from malaria to autoimmunity. Clin Rev Allergy Immunol 2012; 42(2):145-53.

https://doi.org/10.1007/s12016-010-8243-X

41. Sinha N, Balayla G. Hydroxychloroquine and COVID-19. Postgrad Med J 2020; 96(1139):550-5. h t t p s: // d o i . or g/ 10.1136 / postgradmedj-2020-137785

42. Siemieniuk RAC, Bartoszko JJ, Ge L, Zeraatkar D, Izcovich A, PardoHernandez H, et al. Drug treatments for COVID-19: Living systematic review and network meta-analysis. BMJ 2020; 370:m2980.

43. Syarif A. Antihelmintik. In: Gunawan SG, Setiabudy R, Nafrialdi, Instiaty, editors. Farmakologi dan Terapi. $6^{\text {th }}$ ed. Jakarta: Fakultas Kedokteran Universitas Indonesia; 2016. p.556-7.

44. Caly L, Druce JD, Catton MG, Jans DA, Wagstaff KM. The FDA-approved drug ivermectin inhibits the replication of SARS-CoV-2 in vitro. Antiviral Res 2020; 178:3-6.

h t t p s://doi.org/10.1016/j . antiviral.2020.104787 
45. Shahbaznejad L, Davoudi A, Eslami G, Markowitz JS, Navaeifar MR, Hosseinzadeh $\mathrm{F}$, et al. Effects of ivermectin in patients with COVID-19: a multicenter, double-blind, randomized, controlled clinical trial. Clin Ther 2021; 43(6):1007-19.

https://pubmed.ncbi.nlm.nih. gov/34052007

46. Mahmud R, Rahman MM, Alam I, Ahmed KGU, Kabir AKMH, Sayeed SKJB, et al. Ivermectin in combination with doxycycline for treating COVID-19 symptoms: a randomized trial. J Int Med Res 2021; 49(5):3000605211013550.

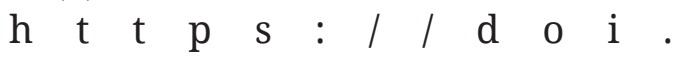
org/10.1177/03000605211013550

47. Kow CS, Merchant HA, Mustafa ZU, Hasan SS. The association between the use of ivermectin and mortality in patients with COVID-19: a metaanalysis. Pharmacol Reports 2021; 73(5):1473-9.

https://doi.org/10.1007/s43440-02100245-Z

48. Aref ZF, Bazeed SEES, Hassan MH, Hassan AS, Rashad A, Hassan RG, et al. Clinical, biochemical and molecular evaluations of ivermectin mucoadhesive nanosuspension nasal spray in reducing upper respiratory symptoms of mild COVID-19. Int J Nanomed 2021; 16:4063-72. https://doi.org/10.2147/IJN.S313093

49. Chahla RE, Medina Ruiz L, Ortega ES, Morales, RN MF, Barreiro F, George $\mathrm{A}$, et al. Intensive treatment with ivermectin and iota-carrageenan as pre-exposure prophylaxis for COVID-19 in health care workers from Tucuman, Argentina. Am J Ther 2021; 28(5):e601-4.

h t t p s://d oi.org/10.1097/ MJT.0000000000001433

50. López-Medina E, López P, Hurtado IC, Dávalos DM, Ramirez O, Martínez $\mathrm{E}$, et al. Effect of ivermectin on time to resolution of symptoms among adults with mild COVID-19: a randomized clinical trial. JAMA 2021; 325(14):1426-35. https://doi.org/10.1001/jama.2021.3071

51. Mohan A, Tiwari P, Suri TM, Mittal S, Patel A, Jain A, et al. Singledose oral ivermectin in mild and moderate COVID-19 (RIVET-COV): A single-centre randomized, placebocontrolled trial. J Infect Chemother 2021; 2:1-7.

https://doi.org/10.1016/j.jiac.2021.08.021

52. Vallejos J, Zoni R, Bangher $\mathrm{M}$, Villamandos S, Bobadilla A, Plano $\mathrm{F}$, et al. Ivermectin to prevent hospitalizations in patients with COVID-19 (IVERCOR-COVID19) a randomized, double-blind, placebocontrolled trial. BMC Infect Dis 2021; 21(1):1-11.

https://doi.org/10.1186/s12879-02106348-5

53. Webb BJ, Peltan ID, Jensen P, Hoda D, Hunter B, Silver A, et al. Clinical criteria for COVID-19-associated hyperinflammatory syndrome: a cohort study. Lancet Rheumatol 2020; 2(12):e754-63.

https://doi.org/10.1016/S26659913(20)30343-X

54. Rubin EJ, Longo DL, Baden LR. Interleukin-6 receptor inhibition in COVID-19 - cooling the inflammatory soup. N Engl J Med 2021; 384(16):1564-5. https://doi.org/10.1056/NEJMe2103108

55. Zhou F, Yu T, Du R, Fan G, Liu Y, Liu Z, et al. Clinical course and risk factors for mortality of adult inpatients with COVID-19 in Wuhan, China: a retrospective cohort study. Lancet 2020; 395(10229):1054-62.

https://doi.org/10.1016/S01406736(20)30566-3

56. REMAP-CAP Investigators, Gordon AC, Mouncey PR, Al-Beidh F, Rowan $\mathrm{KM}$, Nichol AD, et al. Interleukin-6 Receptor Antagonists in Critically Ill Patients with Covid-19. N Engl J Med. 2021; 384(16):1491-502. https://doi.org/10.1056/NEJMoa2100433

57. Abani O, Abbas A, Abbas F, Abbas $\mathrm{M}$, Abbasi S, Abbass $\mathrm{H}$, et al. Tocilizumab in patients admitted to hospital with COVID-19 (RECOVERY): a randomised, controlled, open- 
label, platform trial. Lancet 2021; 397(10285):1637-45.

https://doi.org/10.1016/S01406736(21)00676-0

58. Salama C, Han J, Yau L, Reiss WG, Kramer B, Neidhart JD, et al. Tocilizumab in patients hospitalized with COVID-19 pneumonia. N Engl J Med 2021; 384(1):20-30. https://doi.org/10.1056/NEJMoa2030340

59. Jones SA, Hunter CA. Is IL-6 a key cytokine target for therapy in COVID-19? Nat Rev Immunol 2021; 21(6):337-9.

http://dx.doi.org/10.1038/s41577021-00553-8
60. Mehta M, Purpura LJ, McConville TH, Neidell MJ, Anderson MR, Bernstein EJ, et al. What about tocilizumab? A retrospective study from a NYC Hospital during the COVID- 19 out break. PLoS One 2021; 16(4 April):1-11.

https://doi.org/10.1371/journal. pone.0249349

61. Rosas IO, Bräu N, Waters M, Go $\mathrm{RC}$, Hunter $\mathrm{BD}$, Bhagani $\mathrm{S}$, et al. Tocilizumab in hospitalized patients with severe COVID-19 pneumonia. $\mathrm{N}$ Engl J Med 2021; 384(16):1503-16. https://doi.org/10.1056/NEJMoa2028700 